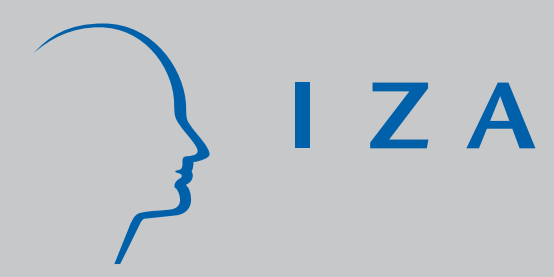

IZA DP No. 1708

Do Women in Top Management

Affect Firm Performance?

A Panel Study of 2500 Danish Firms

Nina Smith

Valdemar Smith

Mette Verner

August 2005 


\title{
Do Women in Top Management Affect Firm Performance? A Panel Study of 2500 Danish Firms
}

\author{
Nina Smith \\ Aarhus School of Business, CIM \\ and IZA Bonn \\ Valdemar Smith \\ Aarhus School of Business \\ and University of Copenhagen \\ Mette Verner \\ Aarhus School of Business and CIM
}

Discussion Paper No. 1708

August 2005

IZA

P.O. Box 7240

53072 Bonn

Germany

Phone: +49-228-3894-0

Fax: +49-228-3894-180

Email: iza@iza.org

Any opinions expressed here are those of the author(s) and not those of the institute. Research disseminated by IZA may include views on policy, but the institute itself takes no institutional policy positions.

The Institute for the Study of Labor (IZA) in Bonn is a local and virtual international research center and a place of communication between science, politics and business. IZA is an independent nonprofit company supported by Deutsche Post World Net. The center is associated with the University of Bonn and offers a stimulating research environment through its research networks, research support, and visitors and doctoral programs. IZA engages in (i) original and internationally competitive research in all fields of labor economics, (ii) development of policy concepts, and (iii) dissemination of research results and concepts to the interested public.

IZA Discussion Papers often represent preliminary work and are circulated to encourage discussion. Citation of such a paper should account for its provisional character. A revised version may be available directly from the author. 
IZA Discussion Paper No. 1708

August 2005

\section{ABSTRACT}

\section{Do Women in Top Management Affect Firm Performance? A Panel Study of 2500 Danish Firms*}

Corporate governance literature argues that board diversity is potentially positively related to firm performance. This study examines the relationship in the case of women in top executive jobs and on boards of directors. We use data for the 2500 largest Danish firms observed during the period 1993-2001 and find that the proportion of women in top management jobs tends to have positive effects on firm performance, even after controlling for numerous characteristics of the firm and direction of causality. The results show that the positive effects of women in top management depend on the qualifications of female top managers.

JEL Classification: G38, J16, M14

Keywords: firm performance, female CEOs, board diversity, gender diversity

Corresponding author:

Nina Smith

Aarhus School of Business

Department of Economics

Prismet, Silkeborgvej 2

DK 8000 Aarhus C

Denmark

Email: nina@asb.dk

\footnotetext{
${ }^{*}$ An earlier version of the paper was presented at the 6th Workshop on Corporate Governance and Investment held in Palma de Mallorca, February 2005. We wish to thank Anna Kossowska for competent assistance in collecting the data and computation work. We also thank Laura Rondi, CERIS-CNR, Torino, and the other participants at the workshop for helpful comments.
} 


\section{Introduction}

During the latest decade, there has been an increasing focus on the gender of top executives and boards of directors of firms. The proportion of women reaching top positions is still very low in most countries, though it has been increasing in for instance the US and in some European countries. Some governments, like in Sweden and Norway, have even introduced regulations of the gender composition of the boards of directors of private firms in order to improve equal opportunities. In Norway, the government has decided that for large Norwegian firms at least $40 \%$ of the members of the boards of directors must be women in 2005. This seems to have had a major impact on the recruitment practices for Norwegian board members, see Hoel (2005). According to Hoel, the proportion of women in Norwegian listed firms increased from about 6\% in 2000 to $22 \%$ in 2005.

Parallel to this discussion, focus has been on good corporate governance in many countries (see for instance for the US TIAA-CREF (2004) and for Denmark Nørby Johansen et al. (2001)). One of the aspects of good corporate governance is diversity management. If it is actually the case that more women (or minority groups) as top executives or members of boards of directors have a positive effect on shareholder value and firm performance, this may be a strong argument for having more women in top management.

In this study, we analyse whether female top executives and women on boards of directors have any significant effect on firm performance measured by alternative performance measures. The study examines the relationship between management diversity and firm performance for the 2500 largest Danish firms observed during the period 19922001. Management diversity is defined as the proportion of women among the highest ranking CEOs in firms and on boards of directors. We estimate various panel data models of 
firm performance and control for factors that are traditionally found to affect firm performance e.g. firms' age, size, sector, export orientation. We find that after controlling for these observed factors, the proportion of women among top executives and on boards of directors tends to have a significantly positive effect on firm performance. A large part of this effect is attributed to the female managers with the best qualifications in terms of education, and for the female board members it appears that the ones representing the staff have the largest positive impact on firm performance. However, when controlling for unobserved firm-specific factors, the effect often turns insignificant. This may reflect that until now very few Danish firms have had women at the CEO level, and thus panel estimates of the performance effects of female CEOs are determined with a large statistical uncertainty. An alternative explanation may be, that the relatively few firms who hire women at the top level of their organization are firms which are also doing well on a number of other unmeasured characteristics (for instance good working conditions and work environment, a more focussed recruitment policy etc.). Another crucial issue is the direction of causality (i.e. do women on boards really affect firm performance or is it actually the case that better performing firms are more likely to hire women?). Therefore, tests for causality between the gender proportion on boards of directors and firm performance are performed. We find that the positive relationship is due to board diversity affecting firm performance, not the opposite.

\section{Theoretical considerations and earlier findings}

There are a number of arguments in favour of diversity of board members to be found in the previous literature, see for instance Bantel and Jackson (1989) and Murray (1989). 
Carter et al. (2003) list 5 positive arguments from a 'business case perspective' and also discuss diversity management in a principal agent framework. Among the arguments pro diversity management is that a more diverse board of directors (or executive board) is able to make decisions based on the evaluation of more alternatives compared to a more homogenous board. A heterogenous board compared to a homogenous board is able to have a better understanding of the market place of the firm, and furthermore diversity increases creativity and innovation. Diversity management may also improve the image of the firm and in this way have positive effects on firm performance and shareholder value if the positive image has positive effects on customers' behaviour. Beside the arguments listed in Carter et al. (2003), another argument for aiming at a more diverse composition of board members is that if only male individuals are potential candidates for the boards, the selection of board members will take place from only this selected distribution of qualifications, and on average this implies a much lower quality than if the candidates are selected among the best from the distribution of both men and women (or include minority groups).

However, there may also be arguments against diversity management. If a heterogenous board produces more opinions and more critical questions, this may be timeconsuming and may not be as effective as a more homogenous board of directors, especially if the firm is operating in a highly competitive environment where the ability to react quickly to market shocks is an important issue. A culturally, ethnically or gender diverse board may experience more conflicts, and even though the decisions may have a better quality in the end, this may not balance the negative effects of a more slow decision-making process if the market place of the firm demands quick responses, see Hambrick et al. (1996). Thus, based on theory, the answer concerning the financial effects of diversity management and women 
on boards is undetermined a priori. Predictions from the previous empirical evidence are ambiguous. Most of the empirical studies have been based on US data, ${ }^{1}$ and most of the studies include only the largest firms. Shrader et al. (1997) analyse the 200 largest US firms and they are unable to find any significantly positive relationship between the percentage of female board members and firm performance (measured by ROA and ROE). They even find significantly negative relations in some cases. Kochan et al. (2003) also find no positive relations between gender diversity in management and firm performance for US companies. Contrary to these findings, Catalyst (2004) and Adler (2001) find positive correlations between 'female-friendly' US Fortune 500 firms and the performance of these firms. Carter et al. (2003) also find a significantly positive effect of the percentage of women and minorities on boards of directors and firm value after controlling for a number of other factors which may affect firm value. The study by Carter et al. (2003) also controls for the direction of causality by estimating an IV-model, see below. A recent study by Bell (2005) based on a large sample of US firms find that women in top management (female top CEO or board members) have a positive effect on the payment of the executives of the firms, and further, these firms also tend to have a higher proportion of women at lower management levels.

Only very few studies from outside the US exist on this topic. Du Rietz and Henrekson (2000) analyse firm performance and women on boards for a sample of Swedish firms. They find that if not controlling for firm size and sectors, firms with women on the board seem to under-perform. However, when controlling for these factors, the underperformance hypothesis could not be confirmed. For Denmark, a recent study by Rose (2004)

\footnotetext{
${ }^{1}$ Carter et al. (2003) give a survey of the empirical results for the US.
} 
did not find any significant relationship between the percentage of women on the boards of directors of the largest listed Danish firms and firm performance (measured by Tobin’s Q).

Thus, the conclusion from the previous empirical studies is ambiguous. Besides the ambiguous theoretical predictions, the diverse empirical evidence may be due to different estimation methods. In some studies, no controls for other factors are included. For instance size and age of the firm (which are factors known to affect firm performance) may correlate with the percentage of females on boards, and thus it may blur the picture if not controlled for. Further, there may be a number of other unobserved factors which are important for firm performance, but which will perhaps never be observable for the researcher. Therefore, panel data where the same firms are observed in a number of years may give a more reliable picture than cross-section studies based on only one year of observation.

A further problem with many of the existing studies is that the samples used are typically only based on the largest (listed) firms for which it is possible to get reliable information. Therefore, the results may not be representative for all firms in a given country. Finally, the direction of causation is important to control for. If well-performing firms decide to employ more women (or minorities) because they decide on a more risky strategy with respect to recruiting board members, the observed relationship between diversity management and firm performance will tend to become positive. If this is the case, causality may run from performance to diversity management and not the reverse.

\section{Data}

In this study, we aim at overcoming a number of the weaknesses in some of the earlier studies by using a rather unique data set based on the 2500 largest Danish firms 
observed during the period 1993-2001. The data set is an unbalanced panel which includes extensive information on the firms and the characteristics of the board members and thus allows us to use panel estimators and control for causality. The data set contains register information from Statistics Denmark who collects information for all Danish firms on a number of firm characteristics for administrative purposes. The information on firms is merged with individual information on the employees of the firm, including information on background characteristics of the CEOs and their spouses. However, since Statistics Denmark does not collect information on for instance board memberships, the information from administrative registers has been merged with information from a private Danish data register KOB (Købmandsstandens Oplysningsbureau). KOB collects information on economic performance, board members of the firms etc. based on annual company reports to the authorities. These reports are publicly available. KOB collects and harmonises this information.

The sample is selected from the administrative registers as the 3000 largest Danish firms, defined by gross turnover of the firms during each of the years 1993-2001. We exclude companies with extreme values, defined as either a negative value of net capital or an extreme relationship between firm's revenue and employment in order to get rid of holding companies etc. This means that the effective sample is reduced to about 2300-2500 firms for each of the years. For some of the variables, for instance membership of board of directors, information is only available for the latest part of the period (1996-2001). The sample is unbalanced, i.e. firms which are close to the cut-off criterion of being among the 3000 largest Danish firms may drop out of the sample in some years. ${ }^{2}$ The sample consists of

\footnotetext{
${ }^{2}$ A potential problem using unbalanced panel data is that firms are entering and leaving the data set and that these changes are likely not to be random. Firm exits depend on performance, which potentially may depend on
} 
listed as well as non-listed firms. In Denmark, there are approximately 300 listed firms. The selection criterium implies that most of these firms are selected into the sample. However, most of the firms included in the data are not listed firms. Consequently, this data set is much broader and more representative compared to the samples used in many other studies of women in management.

Four alternative measures on firm performance are available in the data. We use all four alternative measures in the analyses in order to test the robustness of our results:

1. Gross value added/net turnover

2. Profit on ordinary operations/net turnover

3. Ordinary result/net assets

4. Net result after tax/net assets

Gross value added and profit on ordinary operations are both approximations of the firms’ markup. Gross value added is measured by net turnover minus input expenses (raw materials etc.). Profit on ordinary operations is defined as gross values added minus variable costs of capacity (wages, costs of running machines etc.). Consequently, both measures relate to the firms' basic activities. The ordinary result is defined as the net result of the firm taking into account deductions and financial payments, but not inclusive extraordinary revenues and expenses.

In Denmark, the management of private firms is organized as a two tier system. The board of directors which is chosen by the stockholders typically consists of external board members (except for staff members representing the employees of the firm, see below). The chairman of the board (president) is also usually an external member, i.e. the CEOs are

the gender composition of the board. In order to analyse this potential problem, we have calculated the sample proportion of women in top management for exit and entry firms and tested whether this proportion was higher for exit and entry firms than for firms who stayed in the sample during all years. We did not find any significant differences in the female proportion for entry and exit firms compared to firms who stayed in the sample. 
usually not formally members of the board of directors. In family owned firms, the organization of the management is often different. Here, the top CEO (often member of the owners' families) may also be chairman of the board of directors. Further, it is very common that the board of directors consists of mainly members of the owners' families.

In order to measure gender diversity in management, we apply a number of alternative measures of gender diversity in management. The most restrictive definition includes only the proportion of women among the top CEOs in the firm. ${ }^{3}$ However, as a large proportion of Danish firms have only one top CEO, we also introduce a broader definition of management including vice-directors.

Further, we have information on the proportion of women on the boards of directors. According to Danish law, a number of board members are selected among the staff in firms with more than 35 employees. The number of staff representatives depends on the size of the board. Traditionally, the proportion of women among the board members who represent the staff is larger than among other board members. In some of the estimations, we distinguish between the two types of board members.

In order to control for other factors, which may affect firm performance, a number of other variables are included in the analysis. Firm size is measured by the number of employees, i.e. performance is expected to be positively related to firm size, because larger firms normally have more market power, Bain (1951), Smirlock et al. (1984). Younger firms are expected to have smaller earnings than older ones, because they have less experience in the market, are in a phase of building up their market position, and they normally have

\footnotetext{
${ }^{3}$ The measure which includes only top CEOs is defined as Disco 1, 12, 121 according to the occupational codes applied by Statistics Denmark, while the category 'top CEOs plus vice-directors' also includes Disco 122 and 123.
} 
relatively higher capital costs as compared to older firms. ${ }^{4}$ However, older firms may become more lax or be at a point on their product life cycle with declining earnings. Thus, it may be argued that the effect of firm age is an inverse U-shape. We also control for the export orientation of the firm. Firms that are heavily engaged at export markets (high export/turnover rate) operate in potentially larger markets, and this is expected to affect their profits positively. In line with other studies, we control for potential effects on profit due to entry barriers for the concerned industry by using a measure of the minimum efficient scale (MES) to the market (industry) size, where MES is approximated by the first quartile firm's turnover within the particular industry (measured at the 4-digit level). ${ }^{5}$

Table 1 shows mean statistics for the variables included in the data set. Note that due to missing information, the number of observations varies for each variable. The reported number of observations is the maximum number for the sample. The data is divided into two groups: Firms with at least one female top CEO and firms without any female top CEOs.

(Table 1 about here)

From the table it is seen that firms having at least one female top CEO also have a higher fraction of women in the lower ranks and also in the boards of directors. Thus, there seems to be firms that are more "female-friendly" than others. Considering the means of the four performance measures, there is a tendency of firms with female top CEOs doing worse than firms with no female top CEOs in 2001. There is substantial variation in the proportion of female managers across industries. Some industries (primary sector, energy and water)

\footnotetext{
${ }^{4}$ See e.g. Lipczinsky \& Wilson (2001) p. 144.

${ }^{5}$ MES is calculated by using the total sample of Danish firms which is approximately 25000 firms.
} 
have no firms with a woman among their top CEOs or vice-directors, while other industries are more 'female-friendly' like private service and retail, hotel and restaurants. This clearly indicates substantial industry differences and that this is likely to affect the estimation results.

From Table 1 it appears that mainly older firms and firms with more employees tend to have female managers. However, strong conclusions should not be drawn from these simple descriptive statistics, since other characteristics are not controlled for.

Figure 1 shows the development during the period 1993-2001 in the proportion of women among top CEOs and on boards of directors for all the firms included in this study. In 2001, 4.3\% of the top CEOs in the largest Danish firms were women. When extending the top management category to include vice-directors, this figure increases to $10.9 \%$. The proportion of women on boards of directors was $9.7 \%$ when including staff representatives and $7.9 \%$ when excluding staff representatives.

(Figure 1 about here)

The female proportion among CEOs has been slightly increasing during the 1990s from $2.5 \%$ in 1993 to $4.3 \%$ in 2001 . When including vice-directors, the proportion of women in management has almost doubled, from about 6\% in 1993 to $11 \%$ in 2001. However, the female proportion on boards of directors has declined. It decreased from about 12\% in 1996 to less than $10 \%$ in 2001 . The decline is mainly due to a relative reduction of female members of boards of directors who are not representing the staff. One explanation may be that due to the ethics of good corporate performance, still fewer family members are 
members of boards of directors, and this may have reduced the proportion of women. Our data does not allow us to test this hypothesis.

It is difficult to compare with other countries because of different definitions of top management and variations in the samples selected. But the figures above seem to be relatively low, see Table 2 . The Danish figures based on the sample used in this study include many relatively small firms. According to Table 1 , the average firm size in the Danish sample was 219 employees (2001). If only the 113 largest firms in the sample are considered, the proportion of females among top CEOs was slightly higher (5.9\%) in 2005, see Table 2. However, this is still much lower than in the US Fortune 500 firms where $10.2 \%$ of the top CEOs were women in 2000. In Norway, the proportion of women in boards of directors has risen dramatically the latest years, clearly as a reaction to government regulations in Norway, see Hoel (2005).

\section{Estimation}

\subsection{Basic estimations}

In general, the statistical model of firm performance can be written as,

$$
P_{i t}=\beta_{1} X_{i t}+\beta_{2} W_{-} C E O_{i t}+\beta_{3} W_{-} \text {board }_{i t}+\varepsilon_{i t}
$$

where $i$ refers to the firm, and $t$ is time. $P_{i t}$ is a performance measure. As described in the data section, four performance measures are applied: Gross value added/net turnover, profit on ordinary operations/net turnover, ordinary result/net assets and net result after tax/net assets. $W_{-} C E O_{i t}$ and $W_{-}$board $_{i t}$ are the key variables of this study, i.e. the proportion of women in management, measured as (1) Top CEOs, (2) Top CEOs plus vice-directors, (3) Members of boards of directors. Hence $\beta_{2}$ and $\beta_{3}$ are the parameters of primary interest. $X_{i t}$ 
is a vector of other explanatory variables typically assumed to affect firm performance, i.e. firm size (number of employees), firm age (years since establishment, potential market size (measured by the export-intensity of the firm) $)^{6}$ and an indicator of entry barriers (minimum efficient scale). In addition, we add controls for industry and year of estimation in order to deal with changing business conditions. $\varepsilon_{i t}$ is an error component, assumed to be $\operatorname{Nid}\left(0, \sigma_{\varepsilon}^{2}\right)$.

Since we have a panel of firms, we are able to control for time-constant unobserved heterogeneity which may bias the results from cross-section studies if these unobserved factors correlate with the proportion of female CEOs. Thus, we also present random and fixed effects models of $P_{i t}$. The panel version of equation (1) is:

$$
P_{i t}=\beta_{1} X_{i t}+\beta_{2} W_{-} C E O_{i t}+\beta_{3} W \_ \text {board }_{i t}+\left(\alpha_{i}+\varepsilon_{i t}\right)
$$

where $\alpha_{i}$ is the unobserved heterogeneity term, assumed to be firm-specific and timeinvariant. The random effects estimator is only valid if $\alpha_{i}$ is uncorrelated with the explanatory variables. We test the validity of the random effects estimator by a Hausman test. As shown below, the Hausman test tends to reject the random effects estimator and thus the fixed effects results are preferred.

The fixed effects estimator is consistent, but it does not give any estimates on variables which are time constant. Further, for variables with a small variation, the estimates are imprecise (has a large variation) and therefore results tend to become insignificant due to small variation across time. The key variable in this study, the proportion of women in management, suffers from this problem. Therefore, we first present estimation results from pooled estimations of (1), see Table 3, where selected key results of pooled OLS regressions based on the sample of firms observed during the period 1993 (or 1996 for board of directors

\footnotetext{
${ }^{6}$ The estimation forms allow for non-linearity by including squared expressions for firm size and age, see the theoretical discussion above.
} 
estimations) to 2002 are presented. ${ }^{7}$ For each of the four performance measures, we have estimated four alternative models, including a number of explanatory control variables as described above (firm size, firm age etc.) plus the proportions of women in top management and the share of women on boards of directors. ${ }^{8}$ In the first row of Table 3, the effect of a female top CEO is shown, the second row of results shows the coefficients of the female proportion among top CEOs and vice-directors, the third row shows the coefficients including the variable proportion of women on boards of directors.

\section{(Table 3 about here)}

The first group of results concerns the effect of female top CEOs. In general, the estimated coefficients are positive, but except for column 1 (gross value added/turnover) no significant effects are found. However, extending the definition of top management to include vice-directors, the estimated coefficients turn significant for three out of four firm performance measures. Thus, when controlling for firm size, sector, age of firm etc., we find that there is a positive performance effect of female CEOs for Danish firms.

Turning to the female representation on boards of directors, the results are more mixed. When including a variable measuring the proportion of women among all board members, there is only one positive and significant coefficient found (profit on primary

\footnotetext{
${ }^{7}$ Due to space considerations we do not show the full estimation results for all the models in this paper. The full estimation results are available from the authors upon request.

${ }^{8}$ For different reasons, we do not include both $W_{-} C E O$ and $W \_$board in the same regressions but estimate their effects in separate regressions. Firstly, W_board is only observed for a sub-period, i.e. the years 1996-2001. Second, we are not able to instrument both variables when controlling for reverse causality, and thirdly, the two variables are correlated, i.e. we have problems of multicollinarity. Thus, the 'total effect' of women in top management is not the sum of the two estimated effects.
} 
operations/turnover) while the coefficient for some performance measures is negative, though insignificant.

In order to control for unobserved time-constant heterogeneity, which may affect firm performance, we have also estimated alternative panel data models, where we exploit the fact that the same firms are observed several times. Table A1 in the Appendix shows the results from fixed effects and random effects estimation the model. The reported Hausman tests reject the random effects model in all cases; i.e. the random effects parameters are likely to be biased from correlation between the firm-specific effects and the explanatory variables. Therefore, the preferred panel data specification is the fixed effect model. As expected, the level of significance drops considerably when moving from the pooled OLS to the fixed effect estimation. This may be the result of a very small variation in the explanatory variables, including the key variables on female proportions in top management or measurement errors which reinforce the problems of getting significant coefficients.

We have experimented with including additional explanatory variables in order to test for these effects. For instance, we have information on the R\&D intensity of the particular industry which the firm belongs to. It may be an indicator for willingness to take risks and the level of risk of the environment in which the firm operates. The motivation for introducing such variables is that women are often seen as risk adverse, and therefore a higher proportion of female managers may affect the degree of risk taken by the firm and consequently its performance. On the other hand, R\&D may determine diversity, i.e. female managers may be less likely to be found as top CEOs in high-risk industries. In order to control for risk industries, the firms included in our data were classified according to the R\&D intensity and the well-known Pavitt-taxonomy was introduced instead of using 
traditional industry dummy variables. However, including R\&D or Pavitt-dummies in the performance equation has no notable influence on the estimation results shown above.

\subsection{Direction of causality.}

The direction of causality between firm performance and the proportion of women in management has been widely discussed. Thus, according to this discussion some firms may be observed to have a high proportion of female CEOs because these firms are currently doing well and may be able 'to take the risk' of employing a female CEO. If this is the case, the direction of causality is the reverse in relation (1)-(2), i.e. profitable firms have relatively more female managers than less profitable firms. In order to deal with problems of potential endogeneity in Equation (1)-(2), we estimate the models by the use of an instrument variable approach. The proportion of women in management in the firm is then estimated by the following equation:

$$
W_{-} C E O_{i t}=\alpha_{1} X_{i t}+\alpha_{2} Z_{i t}+v_{i t}
$$

where $X_{i t}$ is a vector of firm characteristics inclusive firm performance, $Z_{i t}$ are the instruments, i.e. factors affecting the proportion of women in management, which at the same time do not affect firm performance, and $v_{i t}$ is an error component, assumed to be $\operatorname{Nid}\left(0, \sigma_{v}^{2}\right)$. Since $W_{-} C E O_{i t}$ is a proportion, $0 \leq W_{-} C E O_{i t} \leq 1$, a linear specification of (2) is inappropriate. Therefore, (3) is estimated by a tobit estimator which takes into account the upper and lower limits of the dependent variable, $W_{-} C E O_{i t}$.

It is a well-known problem to find valid instruments, i.e. Z-variables. In this study, we have individual information on all CEOs employed in the selected firms and the spouses of these CEOs. We use the average length of education of the spouses of the other CEOs in the firm as an instrument. Our hypothesis is that CEOs who are married to well-educated 
spouses (in most cases these are wives) are supposed to be more positive and have a less traditional view on the competences of female CEOs, implying that they are more willing to hire and accept a woman in their own firm as compared to other CEOs who are married to lower educated spouses. Furthermore, the education of the spouse is assumed not to affect the firm performance, which seems plausible. However, we are only able to apply an IVestimator in the models analysing the effects of female CEOs. We do not have individual information on board members since the information on board members does not stem from Statistic Denmark’s administrative registers. Thus, we do not have valid instruments for the regressions where $W_{-}$board $_{i t}$ enters.

In Table 4, the estimates for panel versions of the IV-models are presented. As the previous results show that the fixed effect model is strictly preferred to the random effects model, only models in which the second step is estimated as pooled OLS and fixed effects estimation are presented.

(Table 4 about here)

The results in Table 4 confirm the results presented previously. The estimates from IV-pooled OLS show positive, significant relationships between female CEOs and comparing to the results of Table 3 (pooled OLS, no IV) the introduction of IV to the pooled OLS generates larger and more significant positive effects of women in management. However, the results from IV-fixed effects models are again insignificant. ${ }^{9}$ Thus, our results

\footnotetext{
${ }^{9}$ The first step results of these models (not presented here) show that the instrument, the average length of education of male CEOs, is strongly related to the proportion of female managers in a firm. Formal testing procedures also show that the instrument is valid (i.e. the average length of education of male CEOs does not affect firm performance).
} 
document, that when controlling for causality, there is still a positive effect of female top CEOs and vice-directors. As in Table 3, the size of the effect is larger for the broader group including vice-directors comparing to the effect observed for only top CEOs. One explanation of this evidence may be that the relatively large increase in Denmark during the period 1993-2001 in female proportion of vice-directors reflects that still more highly educated women are now potential candidates for being promoted into top-management due to their qualifications and professional skills. Older female top CEOs may to a larger extent have been selected due to family ties to the owners' families. We will pursue this hypothesis below.

Though we are able to reject a hypothesis of reverse causality in our study, it is important to stress that the interpretation of our results is not as straightforward as it might seem in first instance. Since we find significantly positive coefficients in the pooled OLS estimations, but insignificant panel estimates (fixed or random effects), this may reflect that the firms who have succeeded in hiring female top managers (or who have a large proportion of women as staff members on the board of directors) are the firms with the most ambitious/progressive/active characteristics in general. If there exist unobserved characteristics of this type in the firm, which are (almost) time constant during our observation period, this may at the same time explain that more women are hired in top management. For instance firms with an explicit diversity management policy or, in general, a more ambitious recruitment policy may also in other respects have characteristics not observed (good working environment, high degree of team spirit etc.) which explain firm performance and profits. 


\subsection{Qualification effects}

In the previous analysis, we have not looked at the qualifications of female managers, i.e. the estimated effects are average effects for all women in top management. However, the estimated effects potentially conceal variations in effects of qualifications of the female managers. The hypothesis is that the positive effect of women in top management is larger, the more qualified the female managers are. If many of the women who are observed as top managers in our sample were mainly selected back in time because they were widows or daughters of the owner(s) and not because of their formal qualifications relevant for a position as a top manager, the estimated coefficients above may not give an adequate picture of the potential for a future policy of diversity management and hiring (formally qualified) women as top managers.

In Table 5, the educational distribution of the CEOs is presented. In 1993, 74\% of all female top CEOs in the sample did not have a theoretical education, while this was only the case for 59\% of the male top CEOs. These figures change considerably during the 1990s, and in 2001 only $46 \%$ of female and $44 \%$ of male top CEOs had no theoretical education. The proportion of female top CEOs holding a university degree almost doubled, from $17 \%$ in 1993 to $32 \%$ in 2001, while the same figures for male top CEOs were $30 \%$ and $36 \%$, respectively. Thus, the educational level of female top CEOs has increased much faster than that of male CEOs, and the educational gap has narrowed considerably during the period. When including vice-directors, the picture changes. Female CEOs at the level just below the top CEO are on average as well educated as their male peers. Since the broader category of

CEOs including vice-directors is younger than the group of top CEOs on average, this 
indicates a development over the period 1993-2001 where Danish female CEOs have become still more qualified and have almost closed the qualification gap to their male colleagues.

(Table 5 about here)

In order to test whether the differences in formal competences matter for the estimated performance effects of women in top management, we split the variable W_CEO into three variables which measure the proportion of females among the group of CEOs at different educational levels

$$
W_{-} C E O_{i t}=W_{-} l_{l o n g}+W_{-} M \& S_{i t}+W_{-} E D U_{i t}
$$

where $\mathrm{W} \_$long ${ }_{i t}$ is the proportion of women among the group of CEOs having at least an education at the master level, $\mathrm{W} \_\mathrm{M} \& \mathrm{~S}_{\text {it }}$ is the proportion of women among the group of CEOs having an education at the BA-level or slightly shorter, $\mathrm{W}_{-} E D U_{i t}$ is the proportion of women among the group of CEOs having no education or another education, i.e. non academic education. Consequently, we estimate the form:

$$
P_{i t}=\beta_{1} X_{i t}+\beta_{2} W_{-} \text {long }_{i t}+\beta_{3} W_{-} M \& S_{i t}+\beta_{4} W_{-} \text {Other }_{i t}+\varepsilon_{i t}
$$

Since there are few females in the group of top CEOs, we only estimate (4) for the group of CEOs including vice-directors. The results of these estimations (see Table 6) are striking, in the sense that they show that a large part of the performance gain from female managers can be attributed to the highest educated women for whom the estimated performance effects tend to be much larger than for women with a short or medium theoretic education (except for Column 2, Profit on primary operations). For women with no 
theoretical education, i.e. women who are either unskilled or have a vocational education, the performance effect is larger than for women with a short or medium theoretical education. ${ }^{10}$

(Table 6 about here)

Among the board members, similar mechanisms may play a role. However, in our data only limited information about the board members is available. We do have information on the board member status of the individual, i.e. whether the board member is a staff representative or not. From Table 7 it is seen that the proportion of females among staff board members is substantially higher than among other board members, and furthermore it appears that, contrary to the general negative trend of women in the Danish boards, the female share among the staff members has increased slightly over the observation period.

\section{(Table 7 about here)}

If we assume that women who are selected into the board of directors are as qualified as their male colleagues who are staff representatives on the board of directors, and if a proportion of female non-staff board members have family ties to the owners, we will expect that a potential positive effect of females on boards is larger for female staff members than for female non-staff members. ${ }^{11}$

\footnotetext{
${ }^{10}$ This result may be explained by the fact that short and medium long theoretical educations in Denmark to a large extent are educations related to service and education jobs in the public sector (nurses, teachers, care workers etc.).

${ }^{11}$ We do not have direct information on family ties in our sample. But for the 100 largest Danish firms more than two thirds of all female supervisory board members (excl. staff representatives) have family ties to the owners.
} 
In Table 8, this hypothesis is tested. The first row of estimates corresponds to the estimates for the female board member effects presented in Table 3 where only one small positive significant effect was found. When we split the female board member effects, i.e. estimates two separate performance effects for the female proportion on the board, an interesting picture emerges: 7 out of 8 estimates are now significant and for the staff members of the board the four coefficients are positive and very significant. On the other hand, for female non-staff members of the board the effects are significantly negative and rather large in two out of four cases.

(Table 8 about here)

Thus, female non-staff members of boards of directors seem to have a less positive or even negative effect on firm performance compared to staff members. This finding may indicate that firms who employ family members on their board of directors seem to be less successful with respect to performance compared to firms who do not. ${ }^{12}$

\section{Conclusion}

The purpose of this paper is to evaluate the influence of the proportion of women in management on firm performance. There is a theoretical as well as an empirical motivation for dealing with this issue of corporate governance. In the theoretical section of the paper, we argue that board diversity affects the performance of the firm. However, according to the existing theory the influence can be positive as well as negative. The empirical motivation

\footnotetext{
${ }^{12}$ This corresponds to the results of Bennedsen et al. (2005) who find for a sample of Danish firms that family successions in CEO positions have a negative impact on performance compared to non-family successions.
} 
comes from the increasing focus on the gender composition of top executives and boards of directors of firms. The proportion of women who reach top positions in the business sector is still very low in most countries, though it has been increasing in some countries. In some countries, like Sweden and Norway, it is even considered to regulate the gender composition of the boards of directors of private firms in order to improve equal opportunities. If it can be shown statistically that more female top executives (or other minority groups) or women on boards of directors have positive effects on firm performance, this may be a strong argument for having more women on boards.

Using a sample of the 2500 largest Danish firms over the period 1993-2001, we analyse empirically whether the proportion of female top CEOs or members of boards of directors really affects firm performance. The conclusion is ambiguous and depends both on the measure of performance and the measure of the proportion of women in management. The effect on firm performance of a higher fraction of female top CEOs varies from none to positive. Performance measures which approximate the mark-up, e.g. gross value added, are affected more positively and more significantly than the other performance measures, e.g. net result/assets. Furthermore, the results show that the positive performance effects are mainly related to female managers with a university degree while female CEOs who do not hold a university degree have a much smaller or insignificant effect on firm performance.

Next, female members of boards of directors elected by the staff seem to have positive effects on firm performance. However, this positive effect does not carry over to other female board members, where the effect is negative - a result, which may be explained by the fact that a significant part of the women on boards have family ties to the owners. 


\section{References}

Adler, R.D. (2001), Women in the Executive Suite Correlate to High Profits, Harvard Business Review.

Bain J.S. (1951), Relation of profit rate to industry concentration: American manufacturing, 1936-1940, Quarterly Journal of Economics, 65, 293-324.

Bantel, K.A. and S.E. Jackson (1989), Top Management and Innovations in Banking: Does the composition of the Top Team Make a Difference?, Strategic Management Journal, vol. 10, (Special Issue), 107-124.

Bell, L. A. (2005), Women-Led Firms and the Gender Gap in Top Executive Jobs, IZA discussion paper 1689, IZA, Bonn.

Bennedsen, M., K. Nielsen and D. Wolfenzon (2005): The Family behind the Family Firm: Evidence from CEO Transitions, CEBRWorking Paper 2005-14, Department of Economics, Copenhagen Business School.

Bennedsen, M., K. Nielsen, F Pérez-González and D. Wolfenzon (2005): Inside the Family Firm: The Role of Families in Succession Decisions and Performance, Discussion Paper 2005-14, Centre for Economic and Business Research, Copenhagen Business School.

Carter, D.A., B.J. Simkins and W.G. Simpson (2003), Corporate Governance, Board Diversity, and Firm Value, The Financial Review, vol 38, 33-53.

Catalyst (2003), Women in US Corporate Leadership: 2003’, www.catalystwomen.org

Catalyst (2004), The Bottom Line: Connecting Corporate Performance and Gender Diversity, www.catalystwomen.org

Cotta, M. (2000), Rapport Presenté'du nom de la section du travail, Le Conceil Économique et Social, Paris.

Du Rietz, A and M. Henrekson (2000), Testing the Female Underperformance Hypothesis, Small Business Economics, vol 14(1), 1-10.

Hambrick, D.C., T.S. Cho and M.J. Chen (1996), The influence of top management team heterogeneity on firms' competitive moves, Administrative Science Quarterly, vol. 41, 659684.

Henrekson, M. (2004), Vägar till ökad jämställdhet i svenskt näringsliv, SNS forlag, Stockholm.

Hoel, M. (2004), Kvinner i styrer og ledelse i norsk næringsliv. Kartlegging av ASAselskapene 2004, CCD/Ledelse Likestilling Mangfold, Oslo. 
Hoel, M. (2005), Kvinner i styrer og ledelse i norsk næringsliv. Kartlegging av ASAselskapene 2005, CCD/Ledelse Likestilling Mangfold, Oslo.

Kochan, T., K. Bezrukova, R. Ely, S. Jackson, A. Joshi, K. Jehn, J. Leonard, D. Levine and D. Thomas (2003), The Effects of Diversity on Business Performance: Report of the Diversity Network, Human Resource Management, vol 42 (1), 3-21.

Likestillingssenteret (2001), Likestilingsbarometret 2001, Oslo.

Lipczinsky, J. \& J. Wilson (2001): Industrial organisation - An Analysis of Competive Markets, Prentice Hall, 2001.

Murray, A.I. (1989), Top Management Group Performance and Firm Performance, Strategic Management Journal, Vol 10 (Special Issue, Summer 1989), 125-141.

Nørby-Johansen, L., J. Lindegaard, W. Schmidt and M. Øvlisen (2001), Nørby udvalgets anbefalinger om corporate governance I Danmark, Erhvervs- og Selskabsstyrelsen, Copenhagen.

Rose, C. (2004), Bestyrelsessammensætning og finansiel performance i danske børsnoterde virksomheder - Er Nørby Rapportens anbefalinger til gavn for aktionærerne? WP 2004-2, Institut for Finansiering, Handelshøjskolen i København.

Shrader, C.B., V.B. Blackburn and P. Iles (1997), Women in Management and firm financial performance: an explorative study, Journal of Managerial Issues, fall 1997, vol. 9 (3), 355372.

Smirlock, M., Gilligan T.W. \& W. Marshall (1984), Tobins q and the structure performance relationship, American Economic Review, 74, 1051-60.

TIAA-CREF (2004), Policy Statement on Corporate Governance: http://www.tiaacref.org/pubs/html/governance_policy/board_directors.html

Vinnicombe, S. and V. Singh (2003), Locks and Keys to the Board-room: A Comparison of UK Male and Female Directors, Women in Management Review. 
Table 1. Sample means and standard deviations, 1993 and 2001.

\begin{tabular}{|c|c|c|c|c|}
\hline & \multicolumn{2}{|c|}{2001} & \multicolumn{2}{|c|}{1993} \\
\hline & $\begin{array}{l}\text { Firms with } \\
\text { at least one } \\
\text { female top } \\
\text { CEO }\end{array}$ & $\begin{array}{c}\text { Firms with } \\
\text { no female } \\
\text { top CEO }\end{array}$ & $\begin{array}{c}\text { Firms with at } \\
\text { least one } \\
\text { female top } \\
\text { CEO }\end{array}$ & $\begin{array}{c}\text { Firms with } \\
\text { no female } \\
\text { top CEO }\end{array}$ \\
\hline \multicolumn{5}{|l|}{ Female Proportion: } \\
\hline CEOs & $\begin{array}{c}0.499 \\
(0.300)\end{array}$ & & $\begin{array}{c}0.567 \\
(0.293)\end{array}$ & \\
\hline CEOs and vice-directors & $\begin{array}{c}0.292 \\
(0.204)\end{array}$ & $\begin{array}{c}0.063 \\
(0.154)\end{array}$ & $\begin{array}{c}0.357 \\
(0.269)\end{array}$ & $\begin{array}{c}0.036 \\
(0.114)\end{array}$ \\
\hline Board of directors, excl. staff & $\begin{array}{c}0.139 \\
(0.184)\end{array}$ & $\begin{array}{c}0.067 \\
(0.138)\end{array}$ & & \\
\hline Board of directors, staff only & $\begin{array}{c}0.133 \\
(0.251)\end{array}$ & $\begin{array}{c}0.061 \\
(0.180)\end{array}$ & & \\
\hline \multicolumn{5}{|l|}{ Firm Performance: } \\
\hline Gross value added/net turnover & $\begin{array}{c}0.353 \\
(0.189)\end{array}$ & $\begin{array}{c}0.305 \\
(0.213)\end{array}$ & $\begin{array}{c}0.398 \\
(0.200)\end{array}$ & $\begin{array}{c}0.325 \\
(0.208)\end{array}$ \\
\hline Profit ordinary operations/net turnover & $\begin{array}{c}0.036 \\
(0.101)\end{array}$ & $\begin{array}{c}0.045 \\
(0.106)\end{array}$ & $\begin{array}{c}0.042 \\
(0.058)\end{array}$ & $\begin{array}{c}0.045 \\
(0.078)\end{array}$ \\
\hline Ordinary result/net assets & $\begin{array}{c}0.210 \\
(0.433)\end{array}$ & $\begin{array}{c}0.234 \\
(0.601)\end{array}$ & & $\begin{array}{c}0.707 \\
(1.150)\end{array}$ \\
\hline Net result after tax/net assets & $\begin{array}{c}0.151 \\
(0.345)\end{array}$ & $\begin{array}{c}0.160 \\
(0.357)\end{array}$ & $\begin{array}{c}0.178 \\
(0.459)\end{array}$ & $\begin{array}{c}0.176 \\
(0.355)\end{array}$ \\
\hline \multicolumn{5}{|l|}{ Sector: } \\
\hline Primary & & $\begin{array}{l}0.0151 \\
(0.122)\end{array}$ & & $\begin{array}{c}0.015 \\
(0.122)\end{array}$ \\
\hline Manufacturing & $\begin{array}{c}0.343 \\
(0.477)\end{array}$ & $\begin{array}{c}0.300 \\
(0.459)\end{array}$ & $\begin{array}{c}0.348 \\
(0.481)\end{array}$ & $\begin{array}{c}0.321 \\
(0.467)\end{array}$ \\
\hline Energy and water & & $\begin{array}{c}0.021 \\
(0.142)\end{array}$ & & $\begin{array}{c}0.006 \\
(0.078)\end{array}$ \\
\hline Building and construction & $\begin{array}{c}0.051 \\
(0.220)\end{array}$ & $\begin{array}{c}0.045 \\
(0.208)\end{array}$ & & $\begin{array}{c}0.055 \\
(0.227)\end{array}$ \\
\hline Retail, hotel and restaurants & $\begin{array}{c}0.374 \\
(0.486)\end{array}$ & $\begin{array}{c}0.402 \\
(0.490)\end{array}$ & $\begin{array}{c}0.391 \\
(0.493)\end{array}$ & $\begin{array}{c}0.384 \\
(0.486)\end{array}$ \\
\hline Transportation, telecommunication etc. & $\begin{array}{c}0.040 \\
(0.198)\end{array}$ & $\begin{array}{c}0.050 \\
(0.219)\end{array}$ & $\begin{array}{c}0.043 \\
(0.206)\end{array}$ & $\begin{array}{c}0.044 \\
(0.205)\end{array}$ \\
\hline Private service & $\begin{array}{c}0.192 \\
(0.396)\end{array}$ & $\begin{array}{c}0.166 \\
(0.373)\end{array}$ & $\begin{array}{c}0.217 \\
(0.417)\end{array}$ & $\begin{array}{c}0.175 \\
(0.380)\end{array}$ \\
\hline Age of firm (year) & $\begin{array}{c}40.040 \\
(37.482)\end{array}$ & $\begin{array}{c}32.693 \\
(32.981)\end{array}$ & $\begin{array}{c}43.690 \\
(25.886)\end{array}$ & $\begin{array}{c}38.415 \\
(32.802)\end{array}$ \\
\hline Number of employees & $\begin{array}{c}626.061 \\
(1644.250)\end{array}$ & $\begin{array}{c}201.498 \\
(609.022)\end{array}$ & $\begin{array}{c}352.175 \\
(684.714)\end{array}$ & $\begin{array}{c}154.332 \\
(427.710)\end{array}$ \\
\hline Export: & & & & \\
\hline Low (less than $10 \%$ of turnover) & $\begin{array}{c}0.242 \\
(0.431)\end{array}$ & $\begin{array}{c}0.324 \\
(0.468)\end{array}$ & $\begin{array}{c}0.413 \\
(0.498)\end{array}$ & $\begin{array}{c}0.555 \\
(0.497)\end{array}$ \\
\hline High (more than $50 \%$ of turnover) & $\begin{array}{c}0.737 \\
(0.442)\end{array}$ & $\begin{array}{c}0.659 \\
(0.474)\end{array}$ & $\begin{array}{c}0.261 \\
(0.444)\end{array}$ & $\begin{array}{c}0.203 \\
(0.402)\end{array}$ \\
\hline $\begin{array}{l}\text { Min. efficient scale relative to market size } \\
\text { (MES = quartile turnover in industry, 4-digit) }\end{array}$ & $\begin{array}{c}8.433 \\
(1.334) \\
\end{array}$ & $\begin{array}{c}8.566 \\
(1.351)\end{array}$ & $\begin{array}{c}7.873 \\
(0.914)\end{array}$ & $\begin{array}{c}7.925 \\
(0.962)\end{array}$ \\
\hline Number of firms & 99 & 2,380 & 46 & 2,108 \\
\hline
\end{tabular}

The number of observations included in the last row is the maximum number of firms in the year concerned. For some of the variables there may be fewer observations than this number. 
Figure 1. Proportion of women in top management and on boards of directors, 1993-2001.

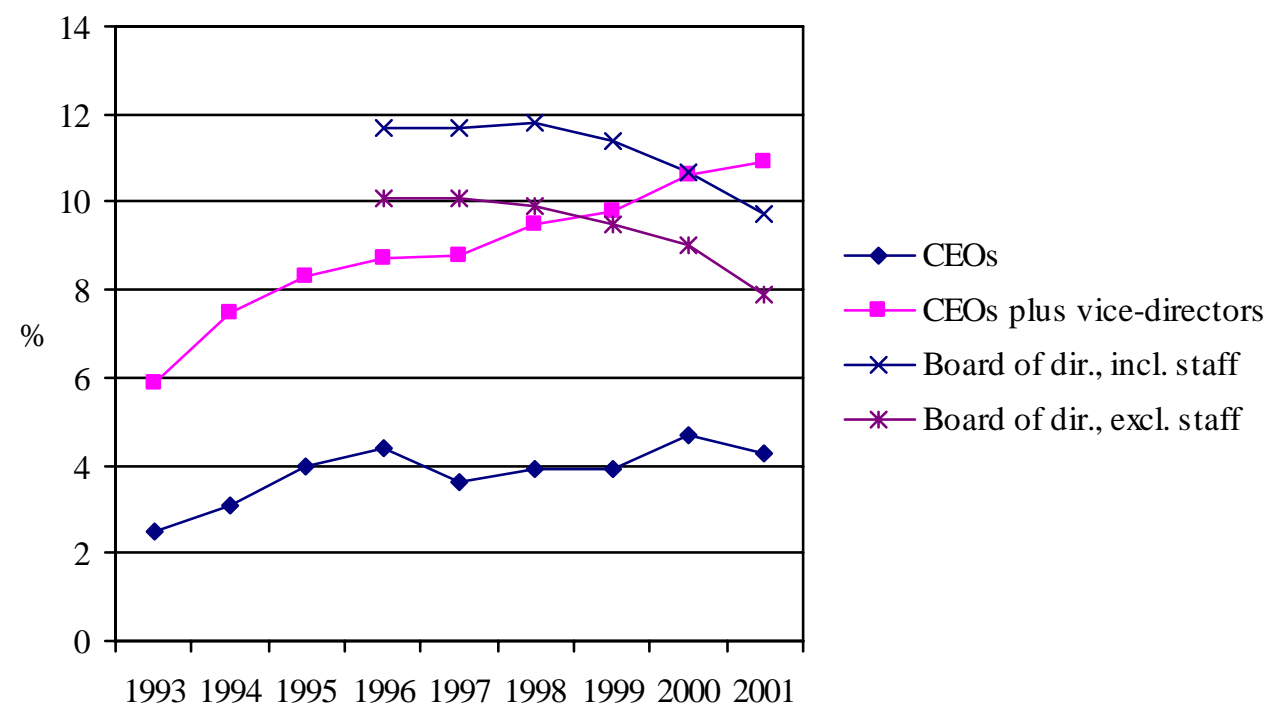


Table 2. Proportion of women in top management (CEO) and on boards of directors, selected countries.

\begin{tabular}{l|cc}
\hline Country & CEO & Board of directors \\
\hline US, Fortune 500 firms, 2000 (CEO)/2002 (board of & $10.2 \%^{1)}$ & $13.6 \%$ \\
directors ) & $1.0 \%$ & $8.6 \%$ \\
UK, FTSE 100 firms, 2002 & $2.9 \%$ & $7.4 \%$ \\
France, 2000 & $5.2 \%$ & $12.0 \%$ \\
Sweden, 2002, large firms (sales > SEK 50 million) & $15.0 \%$ & $18.7 \%$ \\
Sweden 2005 (178 largest firms) & $4.5 \%$ & $6 \%$ \\
Norway, 2001, firms > 250 employees (CEO) and & & $21.6 \%$ \\
listed firms (board of directors ) & $12.4 \%$ & $9.7 \%$ (incl. staff) \\
Norway, 2005 (97 largest firms) & $4.3 \%$ & $7.9 \%$ (excl. staff) \\
\hline Denmark, 2001, 2500 largest firms (sales), this study & & $11.7 \%$ \\
\hline
\end{tabular}

1) A broader definition of top CEO is used than the one used for Denmark.

2) Weighted average calculated on the basis of 380 and 109 firms who had, respectively had not, answered a survey on board membership. Information based on Hoel (2004, p. 13).

Source: US, Catalyst (2003, 2004), UK, Vinnicombe and Singh (2003), France, Cotta (2000), Sweden, Henrekson (2004) and Hoel (2005), Norway, Likestillingssenteret (2001) and Hoel (2004, 2005), Denmark, Hoel (2005). 
Table 3. Estimated coefficients of alternative variables reflecting proportion of women in management $\left(\beta_{2}\right.$ and $\left.\beta_{3}\right)$. Pooled OLS, 1993-2001 ${ }^{1)}$.

\begin{tabular}{l|cccc}
\hline & \multicolumn{4}{|c}{ Dependent variable: Firm performance } \\
\hline & $\begin{array}{c}\text { Gross value } \\
\text { added/turnover }\end{array}$ & $\begin{array}{c}\text { Profit on primary } \\
\text { operations/turnover }\end{array}$ & $\begin{array}{c}\text { Ordinary } \\
\text { result/net assets }\end{array}$ & $\begin{array}{c}\text { Net result after } \\
\text { tax/net assets }\end{array}$ \\
Top CEOs & $0.063 *$ & 0.006 & 0.051 & 0.032 \\
$1993-2001$ & $(0.012)$ & $(0.004)$ & $(0.034)$ & $(0.022)$ \\
& 0.162 & 0.034 & 0.022 & 0.019 \\
& 18,862 & 18,862 & 14,554 & 18,862 \\
Top CEOs & $0.094 *$ & 0.003 & $0.092 *$ & $0.072 *$ \\
and Vice-directors & $(0.009)$ & $(0.003)$ & $(0.027)$ & $(0.016)$ \\
$1993-2001$ & 0.170 & 0.034 & 0.024 & 0.020 \\
& 18,862 & 18,862 & 14,554 & 18,862 \\
& 0.011 & $0.012 *$ & -0.051 & -0.032 \\
Board of directors & $(0.011)$ & $(0.004)$ & $(0.031)$ & $(0.021)$ \\
& 0.160 & 0.034 & 0.022 & 0.018 \\
& 12,085 & 12,085 & 12,080 & 12,085 \\
\hline
\end{tabular}

* denotes that the estimated parameter is statistically different from 0 at the $1 \%$ level of significance.

1) Values in parentheses are standard errors of the estimated parameters, Adj $R^{2}$ is reported in row 3 , and row 4 includes the number of observations in each regression analysis. 
Table 4. Estimated coefficients of alternative variables reflecting proportion of women in management $\left(\beta_{2}\right)$. IV-estimations, $2^{\text {nd }}$ step: pooled OLS and fixed effect estimations, 19932001. Instrument: mean educational level of managers' wives ${ }^{1}$.

\begin{tabular}{|c|c|c|c|c|c|c|c|c|}
\hline & \multicolumn{8}{|c|}{ Dependent variable: Firm performance } \\
\hline & \multicolumn{2}{|c|}{$\begin{array}{l}\text { Gross value added/ } \\
\text { turnover }\end{array}$} & \multicolumn{2}{|c|}{$\begin{array}{c}\text { Profit on primary } \\
\text { operations/turnover }\end{array}$} & \multicolumn{2}{|c|}{$\begin{array}{l}\text { Ordinary result/net } \\
\text { assets }\end{array}$} & \multicolumn{2}{|c|}{$\begin{array}{l}\text { Net result after } \\
\text { tax/net assets }\end{array}$} \\
\hline & $\begin{array}{l}\text { Pooled } \\
\text { OLS }\end{array}$ & $\mathrm{FE}$ & $\begin{array}{l}\text { Pooled } \\
\text { OLS }\end{array}$ & $\mathrm{FE}$ & $\begin{array}{l}\text { Pooled } \\
\text { OLS }\end{array}$ & $\mathrm{FE}$ & $\begin{array}{l}\text { Pooled } \\
\text { OLS }\end{array}$ & FE \\
\hline \multirow[t]{2}{*}{$\begin{array}{l}\text { Top CEOs } \\
1993-2001\end{array}$} & $\begin{array}{l}0.088^{*} \\
(0.008)\end{array}$ & $\begin{array}{l}-0.005 \\
(0.006)\end{array}$ & $\begin{array}{l}0.013^{*} \\
(0.003)\end{array}$ & $\begin{array}{l}-0.003 \\
(0.003)\end{array}$ & $\begin{array}{c}0.074^{*} \\
(0.023)\end{array}$ & $\begin{array}{l}-0.051 \\
(0.035)\end{array}$ & $\begin{array}{l}0.043^{*} \\
(0.014)\end{array}$ & $\begin{array}{l}-0.043 \\
(0.023)\end{array}$ \\
\hline & 0.157 & 0.038 & 0.035 & 0.019 & 0.021 & 0.024 & 0.017 & 0.014 \\
\hline $\begin{array}{l}\text { Top CEOs } \\
\text { and Vice- } \\
\text { directors }\end{array}$ & $\begin{array}{l}0.365^{*} \\
(0.032)\end{array}$ & $\begin{array}{l}-0.019 \\
(0.024)\end{array}$ & $\begin{array}{l}0.053^{*} \\
(0.012)\end{array}$ & $\begin{array}{l}-0.014 \\
(0.015)\end{array}$ & $\begin{array}{l}0.306^{*} \\
(0.095)\end{array}$ & $\begin{array}{l}-0.210 \\
(0.143)\end{array}$ & $\begin{array}{l}0.177^{*} \\
(0.059)\end{array}$ & $\begin{array}{l}-0.178 \\
(0.094)\end{array}$ \\
\hline $1993-2001$ & 0.157 & 0.038 & 0.035 & 0.017 & 0.021 & 0.024 & 0.017 & 0.014 \\
\hline No. of obs. & 17,105 & 17,105 & 17,105 & 17,105 & 17,105 & 17,105 & 17,105 & 17,105 \\
\hline
\end{tabular}

* denotes that the estimated parameter is statistically different from 0 at the $1 \%$ level of significance.

1) Values in parentheses are standard errors of the estimated parameters, Adj $R^{2}$ is reported in row 3, and row 4 includes the number of observations in each regression analysis. 
Table 5. Educational level among female and male CEOs. 1993 and 2001.

\begin{tabular}{|c|c|c|c|c|c|c|c|c|}
\hline & 1993 & & 20 & & & & 20 & \\
\hline & & Top & SEOs & & Top & EOs and & Vice-dire & tors \\
\hline & Women & Men & Women & Men & Women & Men & Women & Men \\
\hline $\begin{array}{l}\text { Long higher } \\
\text { education } \\
\text { (University) }\end{array}$ & 0.174 & 0.298 & 0.315 & 0.358 & 0.239 & 0.228 & 0.289 & 0.309 \\
\hline $\begin{array}{l}\text { Medium or } \\
\text { short higher } \\
\text { education }\end{array}$ & 0.087 & 0.113 & 0.226 & 0.206 & 0.094 & 0.049 & 0.159 & 0.136 \\
\hline $\begin{array}{l}\text { No higher } \\
\text { education/no } \\
\text { info. on educ }\end{array}$ & 0.739 & 0.589 & 0.459 & 0.436 & 0.667 & 0.723 & 0.552 & 0.556 \\
\hline All & 1.000 & 1.000 & 1.000 & 1.000 & 1.000 & 1.000 & 1.000 & 1.000 \\
\hline No. of obs. & 46 & 1020 & 99 & 1142 & 345 & 1322 & 641 & 1408 \\
\hline
\end{tabular}


Table 6. Estimated coefficients on effects of proportion of women in management, top CEOs and vice-directors $\left(\beta_{2}\right)$. Pooled OLS, 1993-2001'.

\begin{tabular}{|c|c|c|c|c|}
\hline \multirow[b]{2}{*}{$\begin{array}{l}\text { Proportion of } \\
\text { female CEO } \\
\text { with: }\end{array}$} & \multicolumn{4}{|c|}{ Dependent variable: Firm performance } \\
\hline & $\begin{array}{c}\text { Gross value } \\
\text { added/turnover }\end{array}$ & $\begin{array}{c}\text { Profit on primary } \\
\text { operations/turnover }\end{array}$ & $\begin{array}{c}\text { Ordinary } \\
\text { result/net assets }\end{array}$ & $\begin{array}{c}\text { Net result after } \\
\text { tax/net assets }\end{array}$ \\
\hline $\begin{array}{l}\text { Long higher } \\
\text { education } \\
\text { (University) }\end{array}$ & $\begin{array}{l}0.284^{*} \\
(0.028)\end{array}$ & $\begin{array}{c}0.012 \\
(0.010)\end{array}$ & $\begin{array}{c}0.152 * * \\
(0.076)\end{array}$ & $\begin{array}{c}0.123^{* *} \\
(0.051)\end{array}$ \\
\hline $\begin{array}{l}\text { Medium or short } \\
\text { higher education }\end{array}$ & $\begin{array}{l}0.017^{*} \\
(0.006)\end{array}$ & $\begin{array}{l}0.0004 \\
(0.002)\end{array}$ & $\begin{array}{c}0.033^{* * *} \\
(0.017)\end{array}$ & $\begin{array}{l}0.021^{* *} \\
(0.011)\end{array}$ \\
\hline $\begin{array}{l}\text { No higher } \\
\text { education/no } \\
\text { info. on educ. }\end{array}$ & $\begin{array}{l}0.061^{*} \\
(0.010)\end{array}$ & $\begin{array}{c}0.008^{* *} \\
(0.004)\end{array}$ & $\begin{array}{l}0.125^{*} \\
(0.027)\end{array}$ & $\begin{array}{l}0.091^{*} \\
(0.018)\end{array}$ \\
\hline Nr. of observations & 12,911 & 12,911 & 9,910 & 12,911 \\
\hline
\end{tabular}

1) Values in parentheses are standard errors of the estimated parameters, Adj $R^{2}$ is reported in row 3, and row 4 includes the number of observations in each regression analysis. 
Table 7. Proportion of women among members of boards of directors including and excluding staff members. 1996 and 2001

\begin{tabular}{l|cc}
\hline & $\mathbf{1 9 9 6}$ & $\mathbf{2 0 0 1}$ \\
\hline Board of directors, all & 0.117 & 0.099 \\
Board of directors, excl. staff & 0.101 & 0.080 \\
Board of directors, staff only & 0.194 & 0.207 \\
\hline
\end{tabular}


Table 8. Estimated coefficients of effects of proportion of women among members of boards of directors $\left(\beta_{3}\right)$. Pooled OLS, 1996-20011).

\begin{tabular}{|c|c|c|c|c|}
\hline & \multicolumn{4}{|c|}{ Dependent variable: Firm performance } \\
\hline & $\begin{array}{c}\text { Gross value } \\
\text { added/turnover }\end{array}$ & $\begin{array}{l}\text { Profit on primary } \\
\text { operations/turnover }\end{array}$ & $\begin{array}{l}\text { Ordinary } \\
\text { result/net assets }\end{array}$ & $\begin{array}{l}\text { Net result after } \\
\text { tax/net assets }\end{array}$ \\
\hline $\begin{array}{l}\text { Board of directors, } \\
\text { all } \\
\text { 1996-2001 }\end{array}$ & $\begin{array}{c}0.011 \\
(0.011) \\
0.160\end{array}$ & $\begin{array}{c}0.012 * \\
(0.004) \\
0.034\end{array}$ & $\begin{array}{c}-0.051 \\
(0.031) \\
0.022\end{array}$ & $\begin{array}{c}-0.032 \\
(0.021) \\
0.018\end{array}$ \\
\hline $\begin{array}{l}\text { Board of directors, } \\
\text { excl. staff } \\
\text { 1996-2001 }\end{array}$ & $\begin{array}{c}-0.009 \\
(0.011) \\
0.171\end{array}$ & $\begin{array}{c}0.007 * * * \\
(0.005) \\
0.038\end{array}$ & $\begin{array}{c}-0.079 * * \\
(0.031) \\
0.029\end{array}$ & $\begin{array}{c}-0.061 * * * \\
(0.021) \\
0.026\end{array}$ \\
\hline $\begin{array}{l}\text { Board of directors, } \\
\text { staff only } \\
\text { 1996-2001 }\end{array}$ & $\begin{array}{c}0.038^{*} \\
(0.010) \\
0.171\end{array}$ & $\begin{array}{c}0.014^{*} \\
(0.004) \\
0.038\end{array}$ & $\begin{array}{c}0.065^{* *} \\
(0.028) \\
0.029\end{array}$ & $\begin{array}{c}0.063^{*} \\
(0.019) \\
0.026\end{array}$ \\
\hline No. of obs. & 12,085 & 12,085 & 12,080 & 12,085 \\
\hline
\end{tabular}

1) Values in parentheses are standard errors of the estimated parameters, $\operatorname{Adj}^{2}$ is reported in row 3, and row 4 includes the number of observations in each regression analysis. 


\section{Appendix}

Table A1. Estimated coefficients of alternative variables reflecting proportion of women in management $\left(\beta_{2}\right.$ and $\left.\beta_{3}\right)$. Fixed-and random effect estimations, 1993-2001 ${ }^{1)}$.

\begin{tabular}{|c|c|c|c|c|c|c|c|c|}
\hline & \multicolumn{8}{|c|}{ Dependent variable: Firm performance } \\
\hline & \multicolumn{2}{|c|}{$\begin{array}{c}\text { Gross value } \\
\text { added/turnover }\end{array}$} & \multicolumn{2}{|c|}{$\begin{array}{c}\text { Profit on primary } \\
\text { operations/turnover }\end{array}$} & \multicolumn{2}{|c|}{$\begin{array}{c}\text { Ordinary result/net } \\
\text { assets }\end{array}$} & \multicolumn{2}{|c|}{$\begin{array}{l}\text { Net result after } \\
\text { tax/net assets }\end{array}$} \\
\hline & $\mathrm{FE}$ & $\mathrm{RE}$ & $\mathrm{FE}$ & $\mathrm{RE}$ & $\mathrm{FE}$ & $\mathrm{RE}$ & $\mathrm{FE}$ & $\mathrm{RE}$ \\
\hline \multirow[t]{2}{*}{$\begin{array}{l}\text { Top CEOs } \\
1993-2001\end{array}$} & $\begin{array}{l}0.020^{*} \\
(0.006)\end{array}$ & $\begin{array}{l}0.023^{*} \\
(0.006)\end{array}$ & $\begin{array}{l}-0.002 \\
(0.004)\end{array}$ & $\begin{array}{l}-0.001 \\
(0.004)\end{array}$ & $\begin{array}{l}-0.022 \\
(0.039)\end{array}$ & $\begin{array}{c}0.005 \\
(0.035)\end{array}$ & $\begin{array}{l}-0.026 \\
(0.024)\end{array}$ & $\begin{array}{l}-0.005 \\
(0.022)\end{array}$ \\
\hline & $\begin{array}{c}0.036 \\
18,862\end{array}$ & $\begin{array}{c}0.029 \\
18,862 \\
1417.5\end{array}$ & $\begin{array}{c}0.017 \\
18,862\end{array}$ & $\begin{array}{c}0.015 \\
18,862 \\
97.2\end{array}$ & $\begin{array}{c}0.023 \\
14,554\end{array}$ & $\begin{array}{c}0.022 \\
14,554 \\
45.6\end{array}$ & $\begin{array}{c}0.014 \\
18,862\end{array}$ & $\begin{array}{c}0.013 \\
18,862 \\
68.5\end{array}$ \\
\hline $\begin{array}{l}\text { Top CEOs } \\
\text { and }\end{array}$ & $\begin{array}{l}-0.002 \\
(0.005)\end{array}$ & $\begin{array}{c}0.005 \\
(0.005)\end{array}$ & $\begin{array}{l}-0.004 \\
(0.003)\end{array}$ & $\begin{array}{l}-0.003 \\
(0.003)\end{array}$ & $\begin{array}{l}-0.019 \\
(0.034)\end{array}$ & $\begin{array}{c}0.022 \\
(0.023)\end{array}$ & $\begin{array}{l}-0.013 \\
(0.020)\end{array}$ & $\begin{array}{c}0.017 \\
(0.017)\end{array}$ \\
\hline 1993-2001 & $\begin{array}{c}0.036 \\
18,862\end{array}$ & $\begin{array}{c}0.028 \\
18,862 \\
2677.1\end{array}$ & $\begin{array}{c}0.017 \\
18,862\end{array}$ & $\begin{array}{c}0.015 \\
18,862 \\
100.4\end{array}$ & $\begin{array}{c}0.023 \\
14,554\end{array}$ & $\begin{array}{c}0.021 \\
14,554 \\
48.2\end{array}$ & $\begin{array}{c}0.013 \\
18,862\end{array}$ & $\begin{array}{c}0.012 \\
18,862 \\
75.1\end{array}$ \\
\hline \multirow{2}{*}{$\begin{array}{l}\text { Board of } \\
\text { directors, all } \\
\text { 1996-2001 }\end{array}$} & $\begin{array}{l}-0.029 * \\
(0.010)\end{array}$ & $\begin{array}{l}-0.024^{*} \\
(0.009)\end{array}$ & $\begin{array}{c}0.002 \\
(0.006)\end{array}$ & $\begin{array}{c}0.003 \\
(0.005)\end{array}$ & $\begin{array}{c}0.015 \\
(0.053)\end{array}$ & $\begin{array}{l}-0.017 \\
(0.039)\end{array}$ & $\begin{array}{l}-0.009 \\
(0.037)\end{array}$ & $\begin{array}{l}-0.014 \\
(0.026)\end{array}$ \\
\hline & $\begin{array}{c}0.062 \\
12,085\end{array}$ & $\begin{array}{c}0.050 \\
12,085 \\
565.4\end{array}$ & $\begin{array}{c}0.018 \\
12,085\end{array}$ & $\begin{array}{c}0.015 \\
12,085 \\
60.0\end{array}$ & $\begin{array}{c}0.021 \\
12,080\end{array}$ & $\begin{array}{c}0.019 \\
12,080 \\
39.1\end{array}$ & $\begin{array}{c}0.017 \\
12,085\end{array}$ & $\begin{array}{c}0.015 \\
12,085 \\
39.7\end{array}$ \\
\hline
\end{tabular}

* denotes that the estimated parameter is statistically different from 0 at the $1 \%$ level of significance.

1) Values in brackets are standard errors of the estimated parameters, Adj. $R^{2}$ is reported in row 3, and row 4 includes the number of observations in each regression analysis. The values reported in row 5 are Hausman Chisquare test for systematic differences in estimated coefficients. 